Original Research Paper

\title{
Ecophysiology of Chirostoma Jordani Pisces: Atherinopsidae. Habitat Characterization and Population Dynamics in a Periurban Lake (Xochimilco, México)
}

\author{
*Latournerié-Cervera José Román, Rangel-Nambo María Isabel and Alma Rosa Estrada-Ortega \\ Laboratorio Transdisciplinario de Acuacultura y Recursos Naturales, Contribución No. 210, \\ Departamento de Biología Comparada, Facultad de Ciencias, Universidad Nacional Autónoma de México (UNAM), \\ Ciudad de México
}

\author{
Article history \\ Received: 24-09-2020 \\ Revised: 07-01-2021 \\ Accepted: 23-01-2021 \\ Corresponding Author: \\ Latournerié-Cervera José \\ Román \\ Laboratorio Transdisciplinario \\ de Acuacultura y Recursos \\ Naturales, Contribución No. \\ 210, Departamento de Biología \\ Comparada, Facultad de \\ Ciencias, Universidad Nacional \\ Autónoma de México \\ (UNAM), Ciudad de México \\ Email: jrlatourneriec@gmail.com
}

\begin{abstract}
Chirostoma Jordani is an endemic species of the Mexican plateau, whose population, due to anthropogenic causes, has experienced a notable decrease from 2000 to the present, putting its permanence in its natural habitat at risk. Therefore, the objectives of this research were focused on evaluating the population dynamics of $C$. Jordani through its size and weight distributions and growth rate during an annual cycle and on determining if there is a relationship of these processes with water quality in the study site. Monthly samplings were carried out from August to November 2014 and from February to May 2015, in the Cuemanco canal, in Xochimilco México. A total of 435 specimens were collected, the smallest sizes and weights were recorded during the months of February and April (indicating a spawning period during this time) and the largest in November. A higher growth rate was recorded in the March-May months, compared to that of August-November $(0.19 \pm 0.05$ and $0.04 \pm 0.03 \mathrm{~mm} /$ day, respectively). The water quality indicators: Temperature, oxygen dissolved, $\mathrm{pH}$ and nitrite, were highly significant in the spatio-temporal variation of the C. Jordani habitat and influenced the abundance and growth of the population. These results lay the foundations to explain the life and performance strategies of the C. Jordani population in Xochimilco, México and are fundamental to the future management of the species in the study area and under controlled conditions.
\end{abstract}

Keywords: Evaluation, Chirostoma Jordani, Management, Population Dynamics, Water Quality, Xochimilco. México

\section{Introduction}

The Xochimilco, México lake system has been affected by multiple anthropogenic pressures, such as the introduction of exotic species, the dumping of wastewater and the overexploitation of its water resources, this has altered the abundance and survival of native species at the site, including the charales of the genus Chirostoma, this taxon was represented by the species: Chirostoma humboldtianum and Chirostoma Jordani, (Saldívar, 2007). However, currently only $C$. Jordani remains at this site. Islas et al. (1995) attribute their permanence to their gradual adaptation to extreme conditions and to the fact that they can resist poor water quality conditions. Nevertheless, as a result of various ecological pressures and human impact in the area, $C$. Jordani populations have experienced a notable decrease, coming to be considered as a species with the possibility of disappearing (Olvera, 2004). That is why the objective of this investigation was to update the status of the residual population of $C$. Jordani in Xochimilco, in order to gather information that would allow the implementation of measures for its conservation and management in the study area.

\section{Materials and Methods}

\section{Samplings}

C. jordani specimens were collected at Cuemanco's canal, in Xochimilco, México. Monthly samplings were carried out from August to November 2014 and from February to May 2015. To capture the organisms, trawls were made with a $0.8 \mathrm{~m}$ rectangular net, $1 \mathrm{~mm}$ mesh 
size, submerged at a depth of approximately $1 \mathrm{~m}$, for 1 min. The captured organisms were transferred to the laboratory, where they were euthanised by immersion in a clove oil solution for $20 \mathrm{~min}$ and later fixed in $10 \%$ formalin for their subsequent analysis.

\section{Environmental Data}

At two points of the Cuemanco canal (near from the intersection with the El Bordo canal and in front of the Real Club España: $\left.19^{\circ} 16^{\prime} 50.37^{\prime \prime} \mathrm{N}, 99^{\circ} 6^{\prime} 7.46^{\prime \prime} \mathrm{W}\right)$, surface and bottom measurements were taken in situ: $\mathrm{pH}$, temperature, ${ }^{\circ} \mathrm{C}$ and total solids, ppt with a HANNA HI98129 multi-analyzer, dissolved oxygen $(\mathrm{mg} \mathrm{O} / \mathrm{l})$ with an oximeter (YSI 55). Water samples were also collected from both strata and then all the samples were kept at $4{ }^{\circ} \mathrm{C}$ for a period of $3 \mathrm{~h}$, prior to their chemical analysis, which included measuring the concentrations of: Ammonia $\left(\mathrm{NH}_{4}\right)$, Nitrite $\left(\mathrm{NO}_{2}\right)$, Nitrate $\left(\mathrm{NO}_{3}\right)$ and Phosphates $\left(\mathrm{PO}_{4}\right)$, with a $\mathrm{HACH} \quad \mathrm{DR} / 870$ spectrophotometer $( \pm 0.005 \mathrm{mg} / \mathrm{L})$.

\section{Population Dynamic Data}

The Total Length (TL) $\pm 0.01 \mathrm{~mm}$ and Wet Weight (WW) $\pm 0.001 \mathrm{~g}$ of all captured organisms were measured. The growth rates and Specific Growth Rate (SGR) percentages (\%) were obtained from the TL and WW size distributions of the organisms from the various samplings, taking into account the average value of the monthly height and weight distribution in consecutive months, according to the (Bhattacharya, 1967) and (Bagenal, 1978) respectively. The relationship between Wet Weight and Total Length $\left(W W=K^{*} T L^{\alpha}\right)$ was also calculated to denote the growth pattern of the organisms. Where $W W$ is the total weight of the fish in grams, $K$ is a regression constant equivalent to the condition Factor $\left(F_{c}\right), T L$ is the total length in $\mathrm{mm}$ and $\alpha$ is the growth coefficient of regression (Ricker, 1975).

\section{Statistical Analysis}

The analysis of the population dynamics was contrasted by means of a unifactorial ANOVA with Tukey's "post hoc" test and $p$ value $=0.05$, the contrast factor being the months of sampling. Multivariate analysis in its discriminant modality was used to compare the possible differences in water quality between the months of sampling, the statistical packages: International Business Machine corporation (IBM SPSS Statistics. 20, 2011) Package for the Social Sciences (SPSS), v. 20 (2011) and Statistical Analysis System (SAS) Jump (JMP), v. 10.0, (SAS Institute, 2012) were used for the various routines.

\section{Results, Literature Reviews and Discussions}

A high environmental heterogeneity was found in the study site: All the measured factors presented significant differences among the sampling months $(\mathrm{p}<0.05)$, except for ammonia which, given its variability, ranged from undetectable to $2.8 \mathrm{mg} / \mathrm{L}$ during August and the period February-March respectively.

The annual thermal range fluctuated between 15.1 and $24.5^{\circ} \mathrm{C}$, the $\mathrm{pH}$ was always alkaline fluctuating between 7.75 and 8.98 , the dissolved oxygen varied from hypoxic conditions in August $(1.3 \pm 2.8 \mathrm{mg} / \mathrm{l})$ to supersaturation levels in September 2014 (12.1 \pm 2.8 $\mathrm{mg} / \mathrm{l})$. Nitrite concentrations reached their maximum levels in October-November (1.2-1.45 mg/L). Nitrate and $\mathrm{P}$-orthophosphate levels recorded concentrations from a hypereutrophic habitat with $95 \%$ Confidence Intervals $\left(\mathrm{CI}_{95 \%}\right)$ of: $27.9-45.1$ and $7.9-13.3 \mathrm{mg} / \mathrm{L}$ respectively. Two factors $\left(\mathrm{O}_{2}\right.$ and temperature $)$ presented significant differences between strata $(\mathrm{p}<0.00)$, contributing to the heterogeneity of the column of water, especially in the warm time of the year.

In Fig. 1, the researchers visualize the multivariate (canonical) means resulting from the discriminant analysis, the ellipsoids indicate the different sampling months, except for April that is represented with asterisks.

At the same time, the vectors resulting from the effect of the variables that were highly significant in the temporal discrimination from this interaction (temperature, $\mathrm{pH}, \mathrm{NO}_{2}$ and dissolved $\mathrm{O}_{2}, \mathrm{p}<0.000$ ) are shown. The resulting model explained $94.9 \%$ of the measured environmental heterogeneity.

Table 1, shows the meristic and growth indicators measured in the C. Jordani population of Xochimilco, 435 specimens were collected during the various samplings, 145 organisms during the period of August-November 2014 and 290 in February-May 2015.

The month with the highest abundance was April ( $n=$ 127 ) and during September and November the catches were of around 30 individuals. The largest specimen was collected during the month of February $(60.18 \mathrm{~mm}$ TL and $1.53 \mathrm{~g} \mathrm{WW}$ ) and the smallest in February and April (0.003 g WW and $4.56 \mathrm{~mm} \mathrm{TL})$, indicating a reproductive peak during the months of January to April.

The comparison of the specific growth rates of TL and WW indicated that the fastest growth of the population occurs in the March-May period of the annual cycle $(1.8-2.1 \% \mathrm{WW} /$ day, which is equivalent to 0.23 $\mathrm{mm}$ /day during this period, around $7 \mathrm{~mm} / \mathrm{month}$ ).

Moreover, in organisms with a size greater than 35 $\mathrm{mm} \mathrm{TL}$, growth is significantly reduced and reaches its lowest values in adults of $42 \mathrm{~mm}$ TL and weight of 0.53 $\mathrm{g} \mathrm{WW}(0.2 \% \mathrm{WW} /$ day), given that these fish channel to a large extent its energy towards the gonads instead of somatic growth, in preparation for the reproductive event, which we detected during the collection in February, where the greatest size dispersions were obtained (Fig. 2 of this study). 
Table 1: Wet Weight (WW), Total Length (TL), Mean \pm SD, specific growth rate (\%day) and $\alpha \pm$ SE = exponent of the alometric relationship $W W=k^{*} T L^{\alpha}$, in monthly samples of Chirostoma Jordani population of Xochimilco. $\mathrm{N}=$ sample size, $r^{2}=$ determination coefficient of alometric relationship, ${ }^{*} \mathrm{p}$ value $(\mathrm{p}<0.000)$. Means with different letters are statistically different $(\mathrm{p}<0.05)$

\begin{tabular}{|c|c|c|c|c|c|c|c|}
\hline Sampling & $\mathrm{N}$ & WW (g) & SGR \%/day & $\mathrm{TL}(\mathrm{mm})$ & $\% /$ day SGR & $\alpha \pm \mathrm{SE}$ & $r^{2}$ \\
\hline A Aug.2014 & 82 & $0.37^{\mathrm{B}} \pm 0.19$ & & $36.91^{\mathrm{A}} \pm 6.02$ & & $2.82 \pm 0.165$ & $0.785^{*}$ \\
\hline sSep.2014 & 32 & $0.47^{\mathrm{A}} \pm 0.32$ & $0.8^{\mathrm{A}-\mathrm{S}}$ & $38.06^{\mathrm{A}} \pm 10.62$ & $0.1^{\mathrm{A}-\mathrm{S}}$ & $3.05 \pm 0.095$ & $0.971^{*}$ \\
\hline NNov.2014 & 31 & $0.53^{\mathrm{A}} \pm 0.28$ & $0.2^{\mathrm{S}-\mathrm{N}}$ & $41.91^{\mathrm{A}} \pm 9.86$ & $0.16^{\mathrm{S}-\mathrm{N}}$ & $3.12 \pm 0.102$ & $0.970 *$ \\
\hline Aug. - Nov & 145 & $0.43 \pm 0.25$ & & $38.23 \pm 8.29$ & & $3.01 \pm 0.076$ & $0.916^{*}$ \\
\hline Febr.2015 & 48 & $0.17^{\mathrm{CD}} \pm 0.30$ & & $22.89^{\mathrm{BC}} \pm 14.79$ & & $2.19 \pm 0.146$ & $0.774 *$ \\
\hline MaMar.2015 & 59 & $0.07^{\mathrm{D}} \pm 0.11$ & & $19.11^{\mathrm{C}} \pm 6.42$ & & $3.12 \pm 0.079$ & $0.965^{*}$ \\
\hline AApr.2015 & 127 & $0.13^{\mathrm{CD}} \pm 0.09$ & $2.1^{\mathrm{Ma}-\mathrm{A}}$ & $25.41^{\mathrm{BC}} \pm 6.32$ & $1.0^{\mathrm{Ma}-\mathrm{A}}$ & $2.99 \pm 0.062$ & $0.949 *$ \\
\hline МyМау.2015 & 36 & $0.22^{\mathrm{C}} \pm 0.19$ & $1.8^{\mathrm{A}-\mathrm{My}}$ & $29.77^{\mathrm{B}} \pm 9.47$ & $0.5^{\mathrm{A}-\mathrm{My}}$ & $2.92 \pm 0.053$ & $0.989 *$ \\
\hline Febr - May & 290 & $0.14 \pm 0.18$ & & $24.08 \pm 8.89$ & & $2.66 \pm 0.057$ & $0.882 *$ \\
\hline
\end{tabular}

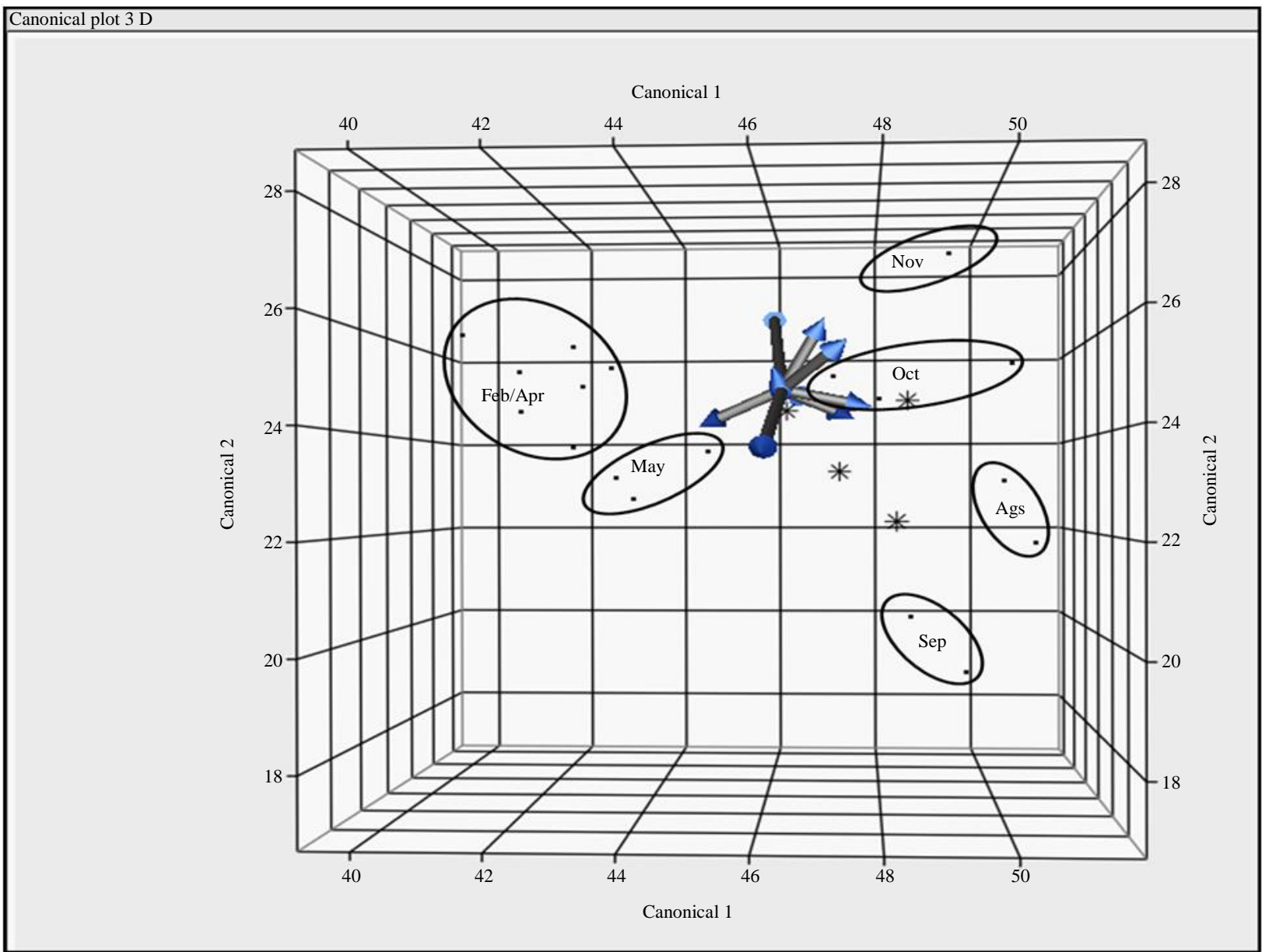

Fig 1: Canonical plot of water quality factors in the habitat of Chirostoma Jordani from Xochimilco during the period Aug. 2014May, 2015

Likewise, the analysis of the WW-TL relationship supports this inference since the exponent $(\alpha)$ during the month of February was the lowest in the annual cycle ( $\alpha$ $=2.19$ ), indicating a mixture of a large proportion of recruits with adult specimens in spawning period, which began to incorporate reserves for the reproduction of the stock from September and continued in this process until March of the following year. During this period, the organisms had a positive allometric growth pattern $(\alpha>$ 3 , denoting a greater growth in weight than in height). 


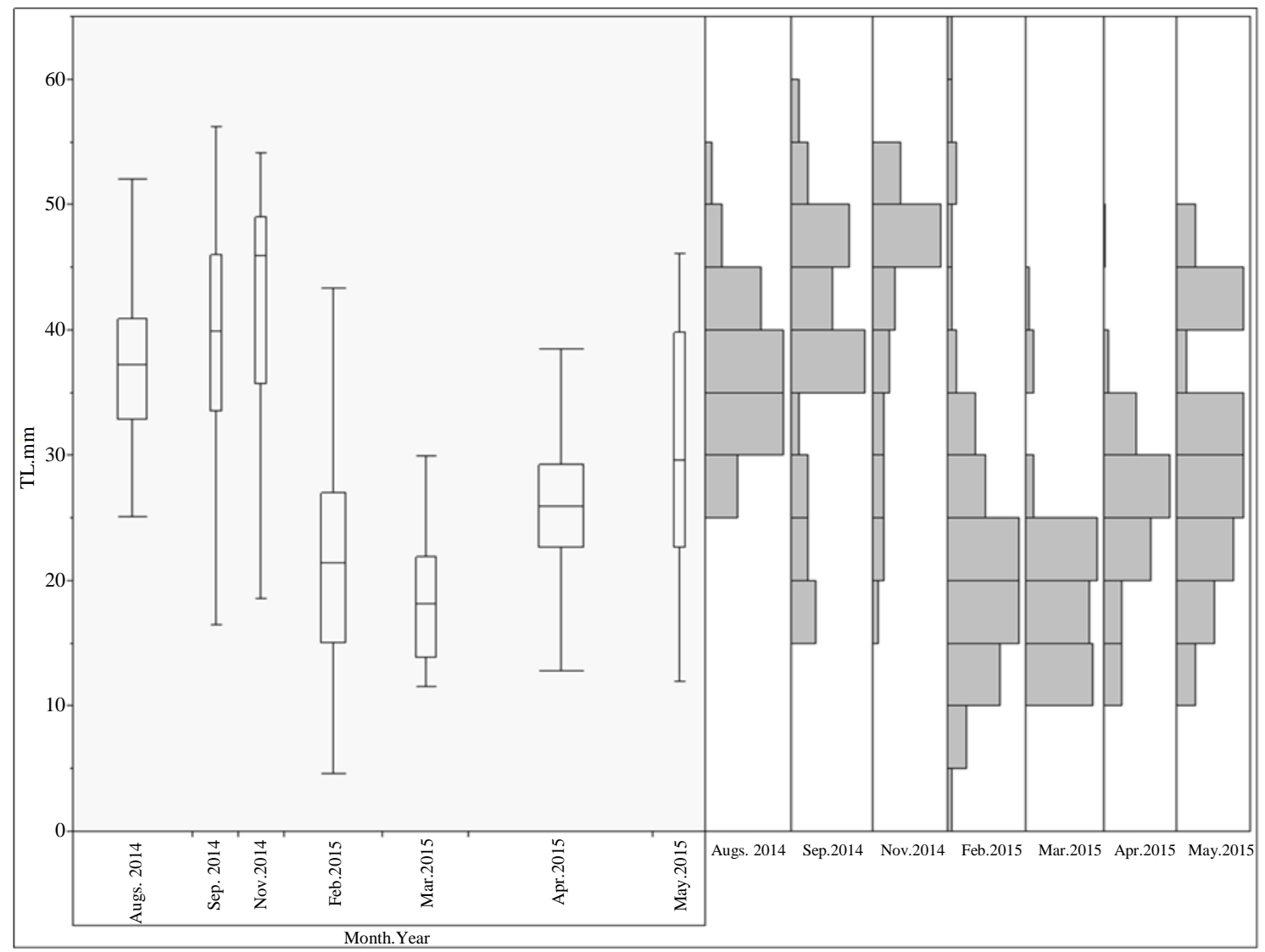

Fig 2: Box plot and frequency distributions of total length of C. Jordani population during the period August 2014-May 2015 in Xochimilco, México

The water quality in the Cuemanco canal is a reflection of the prevailing conditions in the Xochimilco, México channel area. This habitat today is the remnant of the lake complex that covered $1150 \mathrm{~km}^{2}$ in the study area, upon arrival of the Spanish conquerors and is a reflection of how anthropogenic activities in recent decades have contaminated many freshwater environments throughout the planet. The results obtained in the present study generally agree with previous reports that correlate the environmental variability of physicalchemical factors in the study area, in different months of the year (Nandini et al., 2005; Flores-García, 2009).

The physical-chemical factors measured in this study coexist as complex regimes that vary spatially and temporally in their exposure intensities and in turn interact with each other. Within this continuum of factor intensity, the range of stressors is marked by a manifestation of detrimental effects on organisms or ecosystem processes.

On the other hand, nutrients can be chemical stressors, if their concentrations are excessive, because this circumstance amplifies productivity and distorts other ecological functions, for example, causing eutrophication of aquatic ecosystems and in even higher concentrations, nutrients can be toxic (González-Delgado et al., 2002).

For two decades, a decrease in abundance and in the captured sizes of $C$. Jordani in the study area has been reported (Olvera, 2004; Saldívar, 2007). The present investigation confirms these results, since the abundance has decreased even more and the largest size captured only reached $60.18 \mathrm{~mm}$ of TL with a WW of $1.53 \mathrm{~g}$, previous data reported sizes and weights which are no longer reached.

In the dynamic population analysis of $C$. Jordani, the minimum size of $4.56 \mathrm{~mm}$ of TL collected is within the range obtained for newly hatched fry of the species under laboratory conditions, where a value of $4 \mathrm{~mm}$ of TL has been reported at spawning (González, 2009). Our data indicates that in February, the quartile $25 \%$ of the TL distribution, were organisms of around 1 month of age and during March, approximately $60 \%$ of the sample were organisms of 1 to 2 months of age, (Refer to TL distributions: February-March, in Fig. 2 of this study) indicating an accelerated growth of recruits in the 
population. According to (Weatherly et al., 1987), the fact that there is a greater growth in the early stages is because evolutionarily, the fry that gain greater weight and length in their early stages of life have a greater chance of surviving in their natural environment and reach the adult stage, since the larger the organism, the greater the difficulty in swallowing it and its escape speed from possible predators increases, in addition to the advantages it gives in its intraspecific interactions, such as cannibalism.

Meanwhile, the reproductive event is associated with conditions of higher phytoplankton and zooplankton productivity during this period (García et al., 2009). Navarrete-Salgado et al. (2010) pointed out that $C$. Jordani varies its diet depending on the size and availability of food in the environment, presenting eating habits zooplanktophagus. Thus, small-sized organisms feed mainly on the genus Diaptomus and to a lesser extent on Daphnia, Diaphanosoma and Cyclops. The genus most consumed by intermediatesized organisms during spring and summer is Diaptomus and in autumn and winter they consume Daphnia. In large sizes, the main food is Daphnia throughout the year. This seasonal variation in the abundance and availability of the zooplankton genders is in agreement with data from previous reports in the study area (Nandini et al., 2005; García et al., 2009). Furthermore, when food is scarce, there is an increase in intraspecific interactions such as cannibalism (Cházaro-Olvera, 1989). In this sense, (Krebs, 1998) has pointed out that the fact that there is a marked difference in the ingested genders with respect to size organism this is related to a strategy to decrease intraspecific competition between organisms in a population, which decreases the mortality in early stages of the life cycle.

In a recent study (Jardinez-Méndez, 2019), reported the comparison of annual cycles of the C. Jordani population in Xochimilco, indicating an even greater decrease in abundance in 2017 for this species, with even more heterogeneous conditions of the environmental variability of the water quality in the study area, (for example, excessively alkaline $\mathrm{pH}$ values: $9.81 \pm 0.58$ in the month of February, as well as very high levels of ammonia in the months of March and July and an extreme value in nitrite concentrations in the month of October, 2017. This temporality of stressful effects impacted the survival of brood stock, spawning, as well as the surviving fry during the reproductive peak of the population and still exerted their effect on the juvenile stages of the species, translating into lower reproductive potential and decreasing the rate of growth of organisms. It has also been reported that the first stages of development of fish are more sensitive to high total solids concentrations, such as those prevailing in the study area and may even decrease hatching of the eggs (CEPA, 1995).

Other results obtained in our laboratory (Vera-Granados, 2019), indicate that the accumulation of metals: Zinc $(\mathrm{Zn})$, Copper $(\mathrm{Cu})$, Lead $(\mathrm{Pb})$ and Cadmium (Cd) in the tissue of $C$. Jordani exceeds the permissible limits of various international laws and the Official Mexican Norm (NOM, 1993), which results in a potential public health problem due to its possible consumption and in turn has an effect on the charal population on site, impacting its reproduction and growth.

\section{Concluding Remarks}

In summary, as (Freedman, 2018) has pointed out, the exposure of ecosystems to intense anthropogenic stressors of disturbance and pollution would result in changes that degrade ecological integrity and environmental quality. These threats are particularly severe in regions where the human footprint is more intense, that is, where the human population is greater and the economic infrastructure is more developed, as is the case of Xochimilco, México. A key element for mitigating these effects is the need for monitoring and research programs, to detect or predict stressors that are threats to environmental quality and that contribute to the ecological dimension of avoiding or repairing their effects in order to improve the sustainability of both the human economy and the natural world.

\section{Recommendations}

The knowledge generated in this study, should be used to guide decision-making and adjustments to the management plan of the study area (GODF, 2006) by the authorities of the mayor's office, the general direction of protected natural areas and industry, as well as to assist the work of non-governmental organizations and provide material for environmental education.

\section{Acknowledgement}

We thank Master of Science, Fernando Carlos Arana Magallón. Former director of the Centro de Investigaciones Biológicas y Acuáticas de Cuemanco, (CIBAC). UAM-Xochimilco for the facilities granted in the sampling and laboratory infrastructure.

\section{Funding Information}

This research was funded by the Faculty of Sciences, UNAM. 


\section{Author's Contributions}

Latournerié-Cervera José Román:

Conceptualization, Methodology, Investigation, Formal analysis, Writing-Reviewing and editing.

Rangel-Nambo María Isabel: Methodology, Investigation. Writing.

Alma Rosa Estrada-Ortega: Software, Validation, Writing-Original draft preparation.

\section{Ethics}

The authors declare that they have no known competing financial, ethical or personal relationships that could have influenced the work reported in this manuscript.

\section{References}

Bagenal, T. (1978). Methods for assessment of fish production in fresh waters. 3rd. ed. IBP. No. 3 . Blackwell Sci. Publ. Oxford. ISBN:0632001259 https://agris.fao.org/agrissearch/search.do?recordID=US201300555152

Bhattacharya, C., 1967. A simple method of resolution into Gaussian components. Biometrics, 23:115-135. https://www.jstor.org/stable/2528285

CEPA. (1995). Water Quality Control Plan for the San Francisco Bay/Sacramento-San Joaquín Delta Estuary. State Water Resources Control Board. 52p. https://www.epa.gov/sites/production/files/201412/documents/ca-sanfrancisco-bay.pdf

Cházaro-Olvera, S. (1989). Estudio sobre algunos aspectos de la biología del charal Chirostoma jordani en el embalse Trinidad Favela, Estado de México (Doctoral dissertation, Tesis de Licenciatura, ENEP-Iztacala, UNAM, México).

Flores-García, G. A. (2009). Análisis preliminar de algunos factores físico-químicos indicadores de la calidad del agua en Xochimilco. Tesis de Licenciatura en Biología. Facultad de Ciencias, UNAM.

Freedman, B. (2018). Environmental Science: a Canadian perspective. 6th edition. Dalhousie Libraries. Digital Editions. 836p. https://digitaleditions.library.dal.ca/environmental science

García, C. E., Nandini, S., \& Sarma, S. S. S. (2009). Seasonal dynamics of zooplankton in Lake Huetzalin, Xochimilco (Mexico City, Mexico). Limnologica, 39(4), 283-291.

GODF. (2006). Acuerdo por el que se aprueba el programa de manejo del área natural protegida con carácter de zona de conservación ecológica 'Ejidos de Xochimilco y San Gregorio Atlapulco'. Gobierno del Distrito Federal. México: Gaceta Oficial del Distrito Federal.
González, C.P.W. (2009). Ontogenia de Chirostoma jordani (Woolman, 1894) (Pisces: Atherinopsidae) en embriones de vida libre y larvas obtenidas bajo condiciones de laboratorio. Tesis de Licenciatura. FES-Zaragoza. UNAM.

González-Delgado, Ma. N., Orozco-Barrenetxea, C., PérezSerrano, A., Alfayate-Blanco, J. M y J. RodríguezVidal. (2002). Contaminación ambiental. Una visión desde la química. Ed. Paraninfo. Madrid. ISBN 10: 8497321782.

https://www.paraninfo.mx/catalogo/9788497321785/c ontaminacion-ambiental--una-vision-desde-la-quimica

IBM SPSS Statistics. 20. (2011). IBM Corporation. New. Orchard Road Armonk, NY 10504.

Islas, Y.J., Arana, F., \& Pérez, R. (1995). Estudio preliminar sobre la producción en cautiverio de Chirostoma jordani Woolman (Pisces: Atherinidae) de la zona lacustre de Xochimilco, D. F. Segundo Seminario Internacional de Investigación de Xochimilco. Asociación Internacional de Investigadores de Xochimilco A. C.

Jardinez-Méndez, E.C. (2019). Influencia de la época del año y calidad del agua en la dinámica poblacional del charal Chirostoma jordani de Xochimilco. Cd. de México. Comparación de ciclos anuales 2014 y 2017. Tesis de Licenciatura en Biología. Facultad de Ciencias, UNAM.

Krebs, C.J. (1998). Ecological Methodology. $2^{\text {nd }}$ ed. Addison Wesley Educational Publ. New York. ISBN 13: 9780321021731.

Nandini, S., Ramírez-García, P., \& Sarma, S. S. S. (2005). Seasonal variations in the species diversity of planktonic rotifers in Lake Xochimilco, Mexico. Journal of Freshwater Ecology, 20(2), 287-294.

Navarrete-Salgado, N. A., Contreras-Rivero, G., \& Jacobo-Segura, D. L. (2010). Situación de Menidia jordani (Pisces: Atherinopsidae) en el embalse la goleta, Estado de México. Revista Chapingo serie ciencias forestales y del ambiente, 16(2), 165-169.

NOM. (1993). Norma Oficial Mexicana NOM-031SSA1-1993, bienes y servicios. Productos de la pesca. Moluscos bivalvos frescos-refrigerados y congelados. Especificaciones sanitarias.

Olvera, B. (2004). Aspectos poblacionales de Chirostoma jordani (Woolman) (Pisces: Atherinidae), en el sistema lacustre de Xochimilco. Tesis de Maestría. UNAM, México, D.F.

Ricker, W. E. (1975). Computation and interpretation of biological statistics of fish populations. Bull. Fish. Res. Bd. Can., 191, 1-382.

Saldívar, H.S. (2007). Aspectos tróficos del charal Chirostoma jordani (Atherinopsidae) en el Canal Nacional del Lago de Xochimilco. Tesis de Licenciatura. UNAM.

SAS Institute. (2012). JMP 10 Modeling and Multivariate Methods. SAS Institute. 
Latournerié-Cervera José Román et al. / American Journal of Agricultural and Biological Sciences 2021, Volume 16: 1.7 DOI: 10.3844/ajabssp.2021.1.7

Vera-Granados, M. (2019). Evaluación de metales pesados en Chirostoma jordani (Woolman, 1894) en el canal de Cuemanco: Xochimilco. Ciudad de México. Tesis de Licenciatura en Biología. Facultad de Ciencias, UNAM.
Weatherly, A. H., Gill, H. S., \& Casselman, J. M. (1987). The biology of fish growth (Vol. 443). London: Academic press. 